\title{
A Rare Cause of Pneumomediastinum: Foreign Body Aspiration
}

\section{Pnömomediastinumun Nadir Bir Nedeni: Yabancı Cisim Aspirasyonu}

Tolga Semerkant ${ }^{1}$, Hıdır Esme' ${ }^{1}$, Celebi Kocaoglu²

\section{Abstract}

Pneumomediastinum is characterized by the presence of air in the mediastinum. Non-traumatic pneumomediastinum is rarely seen in children, and while the most common cause is asthma, foreign body aspiration should be considered in children younger than 3 years of age. The determinant of the clinical picture in these cases is the severity of dyspnea. Fasciotomy should be performed prior to rigid bronchoscopy, and mediastinal compression should be decreased in the presence of a marked dyspnea. Here, we present the case of a 2-year-old patient with pneumomediastinum secondary to foreign body aspiration, and discuss the alternative approaches to such cases in the light of literature findings.

Key words: Pneumomediastinum, foreign body aspiration, fasciotomy.

\section{Özet}

Pnömomediastinum mediastende hava bulunmasıyla karakterize bir durumdur. Non-travmatik pnömomediastinum çocuklarda nadir olarak görülmektedir ve en sık sebebi, astım olmakla beraber, özellikle 3 yaş altı çocuklarda yabancı cisim aspirasyonu akılda tutulmalıdır. Bu tür olgularda kliniği belirleyen dispnenin derecesidir. Dispne kliniği belirginse rijit bronkoskopi öncesi fasiotomi açılmalı ve mediastinal kompresyon azalıılmalıdır. Burda, 2 yaşında yabancı cisim aspirasyonuna bağlı pnömomediastinumla gelen bir olguda, neler yapılması gerektiğini literatür eşliğinde sunuyoruz.

Anahtar Sözcükler: Pnömomediastinum, yabancı cisim aspirasyonu, fasiotomi.
'Department of Thoracic Surgery, Konya Education and Research Hospital, Konya, Turkey

${ }^{2}$ Department of Pediatric İntensive Care, Konya Education and Research Hospital, Konya, Turkey
'Sağlık Bilimleri Üniversitesi, Konya Eğitim Araşııma Hastanesi, Göğüs Cerrahisi Bölümü, Konya

${ }^{2}$ Sağ lık Bilimleri Üniversitesi, Konya Eğitim Araştırma Hastanesi, Çocuk Yoğun Bakım Bölümü, Konya

Submitted (Başvuru tarihi): 31.05.2020 Accepted (Kabul tarihi): 10.08.2020

Correspondence (iletişim): Tolga Semerkant, Department of Thoracic Surgery, Konya Education and Research Hospital, Konya, Turkey

e-mail: tlgsmrknt@hotmail.com 
The presence of air in the mediastinum is referred to as pneumomediastinum, and subcutaneous emphysema develops as a result of the distribution of this air into the neck, upper extremities and thoracic surface. Pneumomediastinum secondary to foreign body aspiration is rare in children (1). This study analyses a case of pneumomediastinum secondary to foreign body aspiration, subcutaneous emphysema and pneumothorax in the light of currently available literature.

\section{CASE}

A 2 year-old female patient was brought to the emergency service with dyspnea and cough that had been present for almost a day. Upon physical examination, a pulse of $120 /$ min. was determined, while blood pressure and saturation were $110 / 50 / \mathrm{mmHg}$ and $80 \%$, respectively. Diffuse emphysema was palpated in the skin and the subcutaneous tissue of the neck and anterior chest wall. A detailed anamnesis revealed a complaint of emphysema of the skin and subcutaneous tissue that started suddenly before the patient was brought to the emergency service, with a simultaneous onset of dyspnea. Respiratory sounds were decreased in the upper right zone. A chest X-ray revealed accumulated air in the upper mediastinum around the heart and the soft tissues of the neck (Figure 1). Thoracic computed tomography (CT) revealed emphysema in the soft tissues of the chest wall, pneumomediastinum, pulmonary interstitial emphysema at the right upper and middle lobe levels, pneumopericardium and bilateral slight pneumothorax (Figure 2). Furthermore, a soft tissue appearance was seen to be obstructing the right main bronchus, atelectasis was present in the right upper lobe, and air trapping was present in the right middle and lower lobes. The patient was taken to the operating room, where a fasciotomy was performed following general anesthesia to decrease the mediastinal pressure. The organic foreign body was removed from the right upper lobe using 3.5 no rigid bronchoscope (Figure 3). The patient, still intubated, was transferred to pediatric intensive care and was extubated one day after the procedure. The subcutaneous emphysema was found to have completely resolved upon physical examination and a chest $X$-ray on postoperative day 4 (Figure 4). The patient was discharged with a good general condition on postoperative day 5 .

\section{DISCUSSION}

Foreign body aspiration is a common condition in patients aged 1-3 years due to the high tendency in this age group to place objects in the mouth, inadequate chewing, laughing and tendencies to move while eating (2).

Tracheobronchial foreign body aspiration is a lifethreatening emergent condition in childhood, characterized by cough, wheezing and dyspnea in varying degrees. Pneumonia, lung abscess and bronchiectasis can develop in undiagnosed cases, and pneumomediastinum may also develop, although rarely (3). Since pneumomediastinum has many causes, a detailed anamnesis should be obtained and a careful physical examination should be carried out in all cases. Asthma is the most common cause of especially non-traumatic pneumomediastinum, which may be encountered even in the first asthma attack (4). Foreign body aspiration should be investigated in all children, especially those under the age of 3 years, and those presenting with pneumomediastinum (5). The most important criterion in the diagnosis of foreign body aspiration is history of aspiration and choking (1). A detailed anamnesis was obtained in the present study. There was no history of foreign body aspiration in the anamnesis of the patient, who presented with a severe dyspnea and subcutaneous emphysema. Air densities were observed around the pericardium on a chest $X$-ray, and the present clinical picture was thought to be due to an asthma attack, although advanced imaging techniques were used to exclude the diagnosis of foreign body aspiration since the patient was under the age of 3 years, and a thoracic CT revealed a foreign body in the right main bronchus.

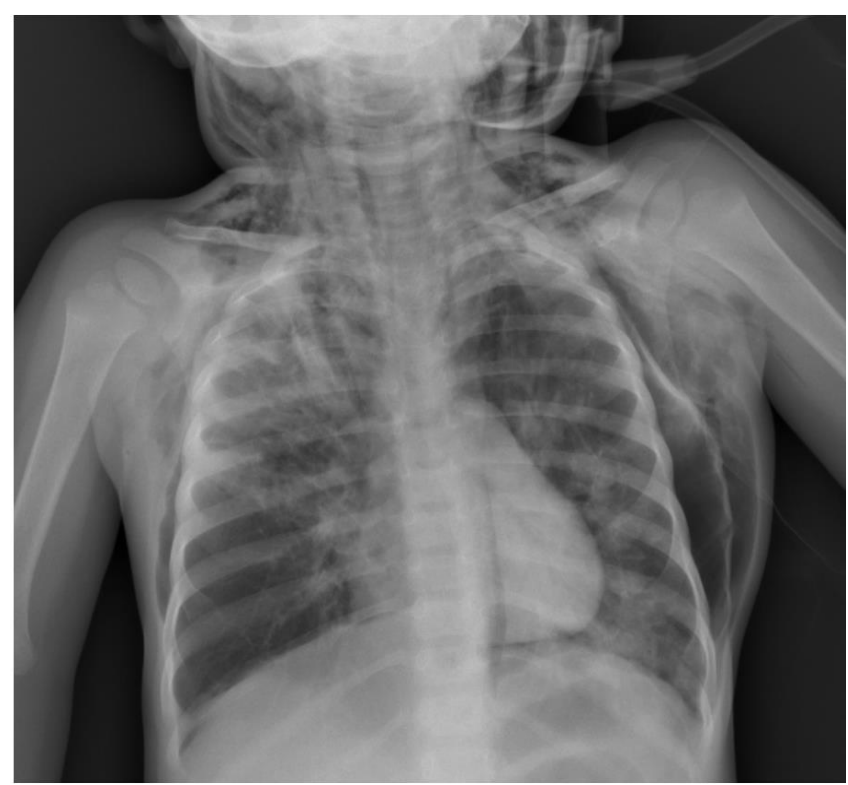

Figure 1: A chest $X$-ray revealed accumulated air in the upper mediastinum around the heart and the soft tissues of the neck 


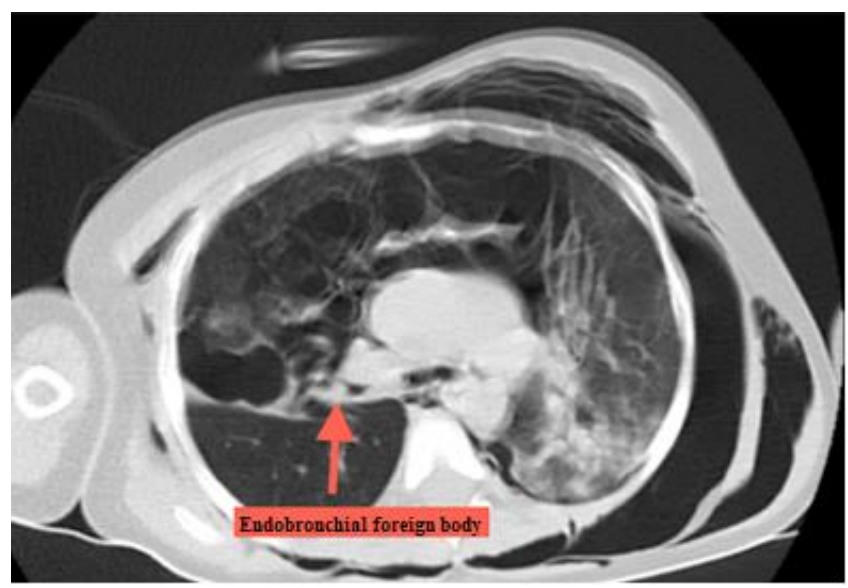

Figure 2: Thoracic computed tomography (CT) revealed emphysema in the soft tissues of the chest wall, pneumomediastinum, pulmonary interstitial emphysema at the right upper, middle lobe levels, pneumopericardium and bilateral slight pneumothorax, and endobronchial foreign body (Red arrow)

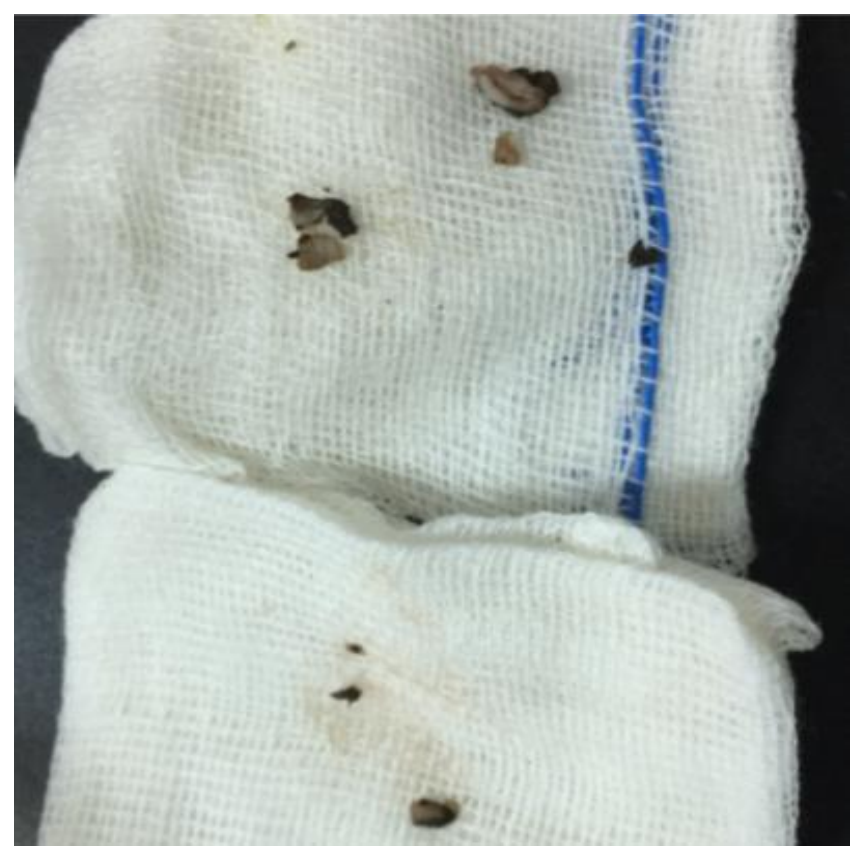

Figure 3: Foreign Bodies

Pneumomediastinum develops when air diffuses from the tracheobronchial tree into the mediastinum via the interstitial and perivascular space, and subcutaneous emphysema subsequently occurs with the diffusion of air into the subcutaneous tissue (6). The incidence of pneumomediastinum secondary to foreign body aspiration is $1.5 \%$. The clinical picture of pneumomediastinum can vary, ranging from chest pain to subcutaneous emphysema, dyspnea, hemodynamic instability and death. The severity of the clinical picture can be determined from the degree of dyspnea (7). Pneumothorax concurrent with pneumomediastinum may also be seen in foreign body aspirations. The mechanism behind the development of pneumothorax can take two forms. First, a foreign body ob- structs the trachea or the bronchus and causes obstructive emphysema, which in turn results in pneumothorax due to the sudden increase in pressure in the lungs. Another mechanism is the direct erosion of the mucosa by a foreign body (4).

In a previous study, the incidence of concomitant pneumomediastinum, subcutaneous emphysema and minimal pneumothorax after foreign body aspiration was reported to be $0.2 \%$, and a severe clinical picture of dyspnea is present in all such cases. An immediate fasciotomy will decrease mediastinal compression, and a subsequent rigid bronchoscopy to remove the foreign body is recommended (8). Diffuse mediastinal and subcutaneous emphysema and slight pneumothorax were present in the present case, together with a severe clinical picture of dyspnea. A fasciotomy was performed to release the mediastinal compression before initiating a rigid bronchoscopy for the removal of the foreign body was removed. At follow-up, the emphysema was found to have completely regressed on postoperative day 4 . The postoperative course of the patient was uneventful, and she was discharged in good health.

\section{CONCLUSION}

Non-traumatic pneumomediastinum is rare in children, and should be investigated cautiously for foreign body aspiration when seen in patients under 3 years of age. An initial fasciotomy should be carried out to decrease mediastinal pressure in patients with a poor general condition, severe dyspnea and pneumomediastinum, followed by a rigid bronchoscopy.

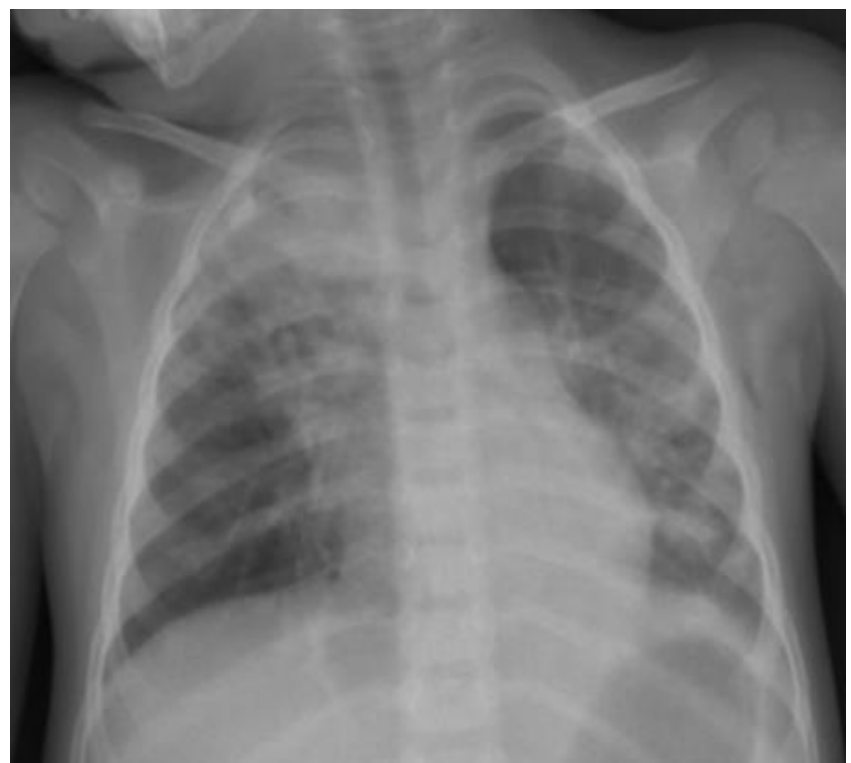

Figure 4: The subcutaneous emphysema was found to have completely resolved a chest $X$-ray on postoperative day 4 


\section{CONFLICTS OF INTEREST}

None declared.

\section{AUTHOR CONTRIBUTIONS}

Concept - T.S., H.E., C.K.; Planning and Design - T.S., H.E., C.K.; Supervision - T.S., H.E., C.K.; Funding - T.S.; Materials - T.S.; Data Collection and/or Processing - T.S., H.E., C.K.; Analysis and/or Interpretation - T.S.; Literature Review - T.S.; Writing - T.S.; Critical Review - T.S.

\section{YAZAR KATKILARI}

Fikir - T.S., H.E., C.K.; Tasarım ve Dizayn - T.S., H.E., C.K.; Denetleme - T.S., H.E., C.K.; Kaynaklar - T.S.; Malzemeler - T.S.; Veri Toplama ve/veya İşleme - T.S., H.E., C.K.; Analiz ve/veya Yorum - T.S.; Literatür Taraması - T.S.; Yazıyı Yazan - T.S.; Eleştirel İnceleme - T.S.

\section{REFERENCES}

1. Bourrous M, Lahmini W, Nouri H, Haimeur N. Subcutaneous emphysema and pneumomediastinum in child with asthma revealing occult foreign body aspiration: a case report. J Med Case Rep 2019; 13:157. [CrossRef]

2. Karaaslan E, Yildiz T. Management of anesthesia and complications in children with Tracheobronchial Foreign Body Aspiration. Pak J Med Sci 2019; 35:1592-7. [CrossRef]
3. Wani NA, Qureshi UA, Kosar TK, Laway MA. Subcutaneous emphysema due to bronchial foreign body demonstrated by multidetector-row computed tomography. Lung India $2011 ; 28: 291-3$. [CrossRef]

4. Fırıncı F, Özgürler F, Doğan M, Koçyiğit A, Mete E. Spontaneous pneumomediastinum in childhood: report of an adolescent case diagnose with asthma. Tuberk Toraks 2014; 62:253-4. [CrossRef]

5. Altuntaş B, Aydın Y, Eroğlu A. Complications of tracheobronchial foreign bodies. Turk J Med Sci 2016; 46:795800. [CrossRef]

6. Passali D, Lauriello M, Bellussi L, Passali GC, Passali FM, Gregori D. Foreign body inhalation in children: an update. Acta Otorhinolaryngol Ital 2010; 30:27-32.

7. Hmami F, Oulmaati A, Boubou M, Benjelloun MC, Hida $M$, Bouharrou A. Subcutaneous emphysema, pneumomediastinum, pneumopericardium, pneumorachis, and pneumoretroperitoneum revealing an unknown foreign body aspiration. Arch Pediatr 2015; 22:978-81. [CrossRef]

8. Yang XJ, Zhang J, Chu P, Guo Y, Tai J, Zhang YM, et al. Pneumomediastinum secondary to foreign body aspiration: clinical features and treatment explorement in 39 pediatric patients. Chin Med J (Engl) 2016; 129:2691-6. [CrossRef] 